\title{
History as geography: In search for Russian identity
}

\author{
Mihhail Lotman \\ Department of Semiotics, University of Tartu \\ Jakobi 2, Tartu 51014, Estonia / \\ School of Humanities, Tallinn University \\ Uus-Sadama 5, Tallinn 10120, Estonia \\ e-mail:mihhail.lotman@gmail.com
}

\begin{abstract}
This article addresses the notion of a Russian spacetime, in which the spatial parameters constitute one of the most important constant of history. This constant is not dependent on the governing ideology. What changes is the evaluative, that is, the most superficial, component; what is a matter of pride for some people, is a discredit to others. Yet nobody seems to contest the dominant of spatiality. In the article, a typology of this betweenness is offered; different Russian ideologists have used all options that are theoretically possible.
\end{abstract}

Keywords: betweenness; binary models; history; Russian culture; Russian space; semiotics of culture; split reality

\section{Binary models in Russian culture}

In a number of crucial publications, Boris Andreevich Uspenskij has demonstrated the fundamentally dualist nature of Russian culture. This refers particularly to Russian medieval culture, but is not limited to just that. Dualism can even be regarded as a semiotic constant of Russian culture (Uspenskij 1994, 1996a, 1998). There are two kinds of dualisms. On the one hand, it is the pronounced binarism, even antitheticality of Russian culture; equipollent oppositions are prevailing, excluding the existence of a neutral sphere (Lotman, Uspenskij 1977). On the other hand, the ontology of Russian culture is itself dual: it is a Christian, even holy country; yet from underneath the Christianity more archaic pagan images and models permeate; the country, which is the basis of "our" identity, can even be a wrong country and "our" real identity is somewhere else, for example, in Heaven or somewhere on earth, usually in the East sometimes it is even called India. At the same time, in Russia itself a secret White 
India is hidden, which is the basis of Russian identity. ${ }^{1}$ Paradoxically, in Russian culture opposite understandings coexist: the notion that Russian culture is absolute and beyond comparison with anything as well as the concepts of being in-between. As Uspenskij notes, binarism is not a specific feature of Russian culture, analogical models can be found also in Western Europe. However, in Russian culture duality is much more total and constitutes the phenomenon which I call 'split reality' (Lotman, M. in press). This is not just a characteristic of Russian medieval culture, but can be regarded as a cultural constant.

In typological studies of this kind, the origin of the model is always a painful problem. Strictly speaking, this is not at all a problem of these studies and it is not possible here to dwell on it more thoroughly. Still, a couple of remarks are in order. The so-called Kievan Rus' was a state formed by Vikings (Lebedev 1995; Uspenskij, F. 2002), like, for example, the Kingdom of Sicily. An important difference from Sicily was that although governmental and especially military structures resembled those of Scandinavia, the intellectual and spiritual culture had mainly Byzantine sources. However, the Byzantine culture was to a great extent censored: ancient paganism, including the entire literary and philosophical tradition of Ancient Greece, was cast out. Poetry was also among the phenomena that had no place in Russian culture. Of course, there were folk songs, but these were not identified as poetry, since the concept was absent from the Russian medieval culture until the 17th century. A vivid example of the depth of this cleanse is that the medieval Russian authors considered verse as an especially sophisticated form of philosophizing and did not associate it with poetry. Nevertheless, the Kievan Rus' was culturally open to both the South and the West. It ended with the Mongol rule, which lasted for a quarter of a millennium and during which Russian culture was encapsulated and conserved. At the end of this period, after the fall of Constantinople, Russia became the most important Orthodox stronghold. Most of the dualist models which became prevailing then, had been present already before that, both in pagan Eastern Slavs and in Kievan Rus', but there had been other models beside these too, which now became extinct.

1 Mythologized messages about India came from Byzantium; an important source here was "A compendious chronicle from various chroniclers and interpreters, gathered together and

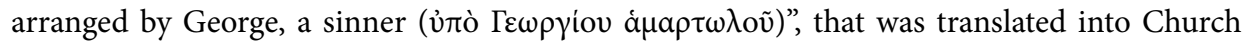
Slavonic in the 11th century. Among other nations (for instance, the Amazons) also a holy nation of (B)rahmans is mentioned. A later source is "The Tale of the Indian Kingdom", which was written in Church Slavonic in Serbia in the 13th-14th centuries as a compilation of different earlier texts; its most important basis is a Latin retelling of a 11th-12th-century Byzantine text. It is essential to stress that, from the beginning, India was not only a geographical, but, first of all, so to speak a hagiographical reality: a holy country or blessed islands often associated with paradise, where the holy nation of rahmans lives (cf. the letter by Bishop Vasilij below, as well as the geographical deliberations by Chaadaev). 
Just as painful is the problem of the inevitability of a model and of the possibilities of breaking it. In his latest works Juri Lotman allowed himself to abandon strict academical discourse, and added some publicistic statements. According to him, the breakdown of the Soviet Union and the democratic processes in Russia provided a historical possibility to escape the binary model: "To overlook this possibility would be a historical catastrophe" (Lotman 2009: 174; see also Lotman 1992). This is the sentence that finishes his last book Culture and Explosion.

Another problem is related to the status of dualism: to what extent does it result from the researcher's metalanguage and to what extent is it characteristic of the culture itself? For such important representatives of the Tartu-Moscow School of Semiotics as Boris Uspenskij, Juri Lotman, Vyacheslav Ivanov and Vladimir Toporov, both are relevant: describing Russian culture with binary oppositions is so efficient because it corresponds to the internal parameters of the culture itself. Here, I allow myself a biographical side note. About fifteen years ago I was sceptical towards the ontological status of binarism and regarded it as a mere methodological device. I shared my doubts with Boris Uspenskij, who, however, stated resolutely that I was mistaken: privative oppositions are highly characteristic of the very essence of Russian culture. At the time I disagreed, but later my own research has increasingly more been persuading me that there was an important point in Uspenskij's argumentation. ${ }^{2}$ The phenomena that seemingly break the dichotomic models, end up being subjected to the same logic. When we speak of such events in Russian culture as Ivan the Terrible's Oprichnina or Peter the Great's reforms, which are both directed towards breaking down the prior paradigm, they, all in all, strengthened it, and often paradoxically. Perhaps the most telling example in this context is St. Petersburg and symbols related to it. Peter wanted to forsake the heritage of Moscow and all associations connected with it, as, for instance, the Third Rome. He even named the new capital with a Dutch name, which referred to his heavenly patron: this was a city of St. Peter. Yet there already was such a city - it was Rome. St. Petersburg's coat of arms contains clear allusions to Vatican's coat of arms. In other words, while Moscow was the Third Rome, St. Petersburg was just Rome (Lotman, Uspenskij 1982). A whole number of ambivalent antitheses related to it form this mythopoetic complex which Vladimir Toporov later called the Petersburg text (Toporov 1984: 200; see also Lotman 1984).

Not only the rulers, but also members of the aristocracy, first of all its educated part, made an attempt to break the prevalence of binarism. We are not talking about such rebels as Alexander Radishchev or Mihail Shcherbatov - their ideas and deeds fit the domineering paradigm perfectly, the poles of oppositions are simply reversed,

2 The only thing that I was convinced of then and am now is that between the ontology of culture and constructed models there is a huge sphere of different discursive practices. This is not, however, the place to discuss this problem. 
but about such people as Mihail Muravyov, Nikolaj Karamzin and their circles. They escaped from the domineering world of thought to their private lives and they both had a significant influence, first of all, in the sphere of literature. Nikolaj Novikov and other freemasons who played an important role in the second half of the 18th century and at the beginning of the 19th century deserve special mention here. Of course, there were other circles too, which are not well studied to this day, as, for example, homosexual brotherhoods; the women's quiet world is also poorly explored.

What is important here, is that all the mentioned phenomena could produce a bright flash, but did not form a consistent narrative, and, all in all, were incorporated into dual models. Compare what happened to the philantropic freemasons in the later dominant discourse: they became enemies of mankind, being especially dangerous for Russia and the Russians. The fate of Pyotr Chaadaev, whom Osip Mandelstam called the first private person in Russia is especially characteristic in this context. Even more intensely than Karamzin, Chaadaev tried to change the paradigm of Russian culture without belonging to any intellectual groups. His heritage, however, was divided by Slavophils and Westerners, while both groups took from Chaadaev only what seemed suitable for them. Thus, Chaadaev was transplanted into the domineering Russian narrative, paradoxically, on both sides of the opposition.

This needs a terminological and methodological explanation. From the three types of oppositions (equipollent, privative and gradual) distinguished by Nikolaj Trubetzkoy, the first two are mainly used in the semiotics of culture, and while on the meta-level first of all privative oppositions are operated with, on the object-level equipollent oppositions are more usual, especially when we are dealing with Russian culture. Russian culture, however, has another important kind of opposition that Dmitri Segal called the ambivalent antithesis in his analysis of Osip Mandelstam's poetry: oppositeness vs. sameness, for example, love and death in one of Mandelstam's poems or heaviness and tenderness in another etc. (Segal 1992: 450-452). Usually, the basis of oppositeness-sameness is formulated as well, so that, for instance, tenderness and heaviness are sisters in another poem by Mandelstam, while in his short story "Egyptian stamp" the criminal and his victim are regarded as same, since they both participate in the action, at least passively. The ambivalent antithesis is not just specific to Mandelstam, similar semantic constructions have been described in Pushkin's and Bulgakov's works (Javornik 1994; Kalokh-Vid 2014) - for example, in Bulgakov, Moscow is at the same time (holy) Jerusalem and (sinful) Babylon (Kalokh-Vid 2014: 45-47).

The ambivalent antithesis is not just a phenomenon characteristic of Russian literature, this mechanism is deeply rooted in Russian culture. For example, due to the ambivalent antithesis, Moscow can be both the Third Rome as well as the New Jerusalem, while Rome and Jerusalem are not the same, but opposed. Here lies the phenomenon of split reality in a more general sense. 
The perception of split reality is connected not only with space, but also with the most different dimensions of reality, for example, time. To give an example: in Russia, just like in all European countries, the Gregorian calendar is valid, but the church lives according to the Julian calendar. There have been discussions over changing to the Gregorian calendar, but it has always been rejected. Different reasons have been proposed, but one of the most important ones is that the Julian calendar would be more accurate. This standpoint is shared not just by the orthodox theologians, but astronomers connected with the church: the Julian calendar is more correct than the Gregorian one (Chkhartishvili 2000). ${ }^{3}$ Yet there is one more aspect: there is a pattern not in the theology, but in the sociopsychology of Russian orthodox culture, according to which church life is holy and right and thus, in daily life, time should be measured differently. Hence some practical dilemmas arise. A few years ago the following discussion evolved online. An orthodox woman turned to her priest and asked, if her family could celebrate the New Year with a glass of sparkling wine. Of course not, said the priest, since the New Year's Eve (31 December) falls on the Nativity (or Philippian) Fast. So, you cannot drink champagne during the fast. Another, more liberal priest joined the discussion, who said that of course it is not recommended, but one glass of wine is allowed. But none of the participants, neither the woman nor the priests thought of the fact, that according to any calendar, Christmas (25 December) cannot come after New Year's Eve (31 December). The participants of the discussion celebrated Christmas in conformity with the Julian calendar, and New Year in conformity with the Gregorian one. If the Julian calendar is more correct and they lived by it, there would not be any problems: Christmas would be on 6 January according to the Gregorian calendar, and New Year's Eve on 14 January. However, their consciousness is split and therefore they live in split reality, in which Christmas is before and after New Year's Eve at the same time.

The opposition of the Gregorian and Julian calendars in contemporary Russian culture is ambivalent, reality lies between these two. Sometimes, however, the ambivalent opposition of these calendars takes an entirely different form. According to some authors, the Orthodox church cannot change to the Gregorian calendar, since in this case, the Orthodox resurrection can coincide with the Jewish Pesach, which would be completely unacceptable (Chkhartishvili 2000). Here we are not dealing with astronomical or pseudoastronomical argumentation, but with the need of distinction:

3 Alexandr Chkhartishvili claims that he is an astrophysicist and his argumentation is scientific. However, it is not. A scientific approach would mean that he would search for the calendary form which best matches the astronomical data (which are given). For Chkhartishvili, the result is given (the Julian calendar is the best), one needs to find astronomical data and a mathematical method which would support this result. Such modus operandi is good neither for science nor theology. 
behind the privative opposition 'West vs. Russia' is an underlying ambivalent antithesis 'Orthodoxy vs. Judaism'.

This requires an explanation. According to Aleksander Chkhartishvili (2000), the Julian calendar has to be preferred by Christians, since it was used during Christ's life and his crucifixion. This is a bizarre claim, since Christ certainly did not live in accordance with the Romans' calendar and his resurrection was on 16 Nisan, i.e., during the Pesach. Does it mean that the Orthodox Church and the whole of Russia should change to the Jewish calendar? ${ }^{4}$ The defenders of the Julian calendar would like to appeal to tradition, but they cannot, since the Julian calendar is not traditional in the Russian culture: it was introduced by Peter the Great on 1 January, 1700, and since then, New Year has started with 1 January (the last New Year according to the old calendar was celebrated on 1 September, 7208, that is, four months earlier). Appealing to Peter is impossible, since traditionalists hate him and his reforms.

The fact that the Julian calendar is preferred has an important consequence: for the most time, one lives in accordance with a wrong calendar, a wrong time. Even in the moments when one lives in accordance with the right time (first of all, Christmas and Passover), the profane time can be sensed (the celebration of Christmas on 6 January). Yet - and this is important - it is right to live in this wrong time, since a (Western) European does not even notice living in wrong time.

The popular saying that Soviet people think one thing and say another is an oversimplification: the doubling is much deeper and permeates the entire world of thought. George Orwell's doublethink is a much more adequate concept: "Doublethink means the power of holding two contradictory beliefs in one's mind simultaneously, and accepting both of them" (Orwell 1950: 214). Orwell had in mind Soviet reality, but the model described by him is a bit too straightforward and simplistic: we are not dealing with two contradictory ideas in one consciousness, but the doubling of the consciousness itself; every world of thought is intrinsically coherent (or at least seems to be), they do not even communicate with one another and there is no discomfort until the problem of celebrating New Year's Eve arises.

It is not only the described dualism that deserves attention, but also its status, which is at the same time perceived and not perceived. The situation with language is more complicated and simpler at the same time. The medieval diglossia has been thoroughly described by Boris Uspenskij. We have every reason to approach Church Slavonic language as the medieval Russian literary language (Uspenskij 2002: 23). Diglossia is not a specific feature of Russian medieval culture, it could be regarded as a

4 The calendar used by the Russian Orthodox Church is not the one used in the Roman Empire in the lifetime of Christ, but it is the so-called Byzantine calendar reformed by Peter the Great. The Byzantine calendar was not used in the lifetime of Christ either, but was created in the 5th century and officially implemented centuries later. 
universal of medieval culture, being characteristic of not just the European (Christian) Middle Ages, but also of Islamic and Far Eastern cultures. In comparison with Western Europe, it has its own specifics: (a) Church Slavonic resembles Russian and was on the whole comprehensible; (b) the Russian Middle Ages still lasted in the 17th century (the beginning of the new era can be dated with Peter's reforms).

Yet what is most important is the fact that the Church Slavonic language is still the basis of the Russian literary language. The purpose of the reforms by Peter I at the beginning of the 18th century was a change in the paradigm of culture, orienting on the Protestant models of Western Europe. The turn to secularity, which in the West took place already during the Renaissance, reached Russia during Peter's reforms. Peter saw to the secularization of literary culture as well, composing himself a new, so-called civilian alphabet (гражданский жрифm, which was also called the Alphabet of Amsterdam) to replace the Church Slavonic alphabet. The language itself, however, was reformed later, in the middle of the 18th century, and here the central figure was Mikhail Lomonosov. While for Peter, the elements of Church Slavonic were an obstacle, Lomonosov, on the contrary, considered them an important resource of the Russian language. In his short essay "On the usefulness of church books for the Russian language" (Lomonosov 1952) he completely disregarded the content of church books and claimed that the benefit arising from them lies in their language, and this language is not Russian, but Church Slavonic. According to Lomonosov, in high style it is allowed to use only the words which are both in Russian and Church Slavonic. Since the prevailing part of this common vocabulary is of Church Slavonic origin, the latter became the basis for the Russian literary language. As Boris Unbegaun (1971) formulated it: Church Slavonic absorbed Russian. Other Russian words from the literary and the spoken languages come from different sources, being regarded simultaneously as opposite and the same.

\section{Typology of cultural betweenness}

Thus, two antithetical mechanisms constitute the basis of the identity of Russian culture, one of which is sovereignty and the second - relations to others. Being inbetween is itself an ambivalent and complex phenomenon. In typological terms, we can distinguish, first of all, between three main types of relations: interaction, alliance and identity. Each of these, in turn, offers other different possibilities. 


\begin{tabular}{|c|c|}
\hline \multicolumn{2}{|r|}{ I. Interaction: } \\
\hline MEDIATOR: $\mathrm{A} \rightleftarrows \mathrm{X} \rightleftarrows \mathrm{B}$ & $\begin{array}{l}\text { Culture is open to both directions and, while becoming } \\
\text { richer, enriches both the Western and the Eastern worlds. } \\
\text { In Russian culture, this idea was expressed, for example, } \\
\text { by Nikolaj Berdyaev (1910, 1918), or, to be more exact, } \\
\text { according to him Russia should strive for becoming such } \\
\text { mediator. The philosopher Arsenij Gulyga is even more } \\
\text { direct: "Russia is a mediator between the East and the West" } \\
\text { (Gulyga 1995: 163). }\end{array}$ \\
\hline MEMBRANE: $\mathrm{A} \rightarrow \mathrm{B}$ & $\begin{array}{l}\text { Culture is a semiconductor, which transmits ideas and } \\
\text { influence in one direction. In regard to Russia, the main } \\
\text { focus was the mission of Europeanization in Asia, at least it } \\
\text { was the semiofficial ideology in the 19th century imperial } \\
\text { Russia. On the other hand, a number of Russian mystics } \\
\text { related to theosophy (Pyotr Ouspensky and others) claimed } \\
\text { that the Russian mission was to translate Eastern wisdom } \\
\text { for the (Western) world. }\end{array}$ \\
\hline ISOLATOR: A || B & $\begin{array}{l}\text { Culture separates and becomes separated, isolates and } \\
\text { becomes isolated. In Soviet Russia, this was especially } \\
\text { clearly expressed at the end of the 1940s and the beginning } \\
\text { of the 1950s. Fighting against cosmopolitism and } \\
\text { cosmopolites, as well as fighting against servility towards } \\
\text { the West were the official slogans of this time. Yet such } \\
\text { ideas are so widespread even today that President Putin } \\
\text { held it necessary to refute these even twice within one } \\
\text { speech: "The calls to [Russian] self-isolation were resolutely } \\
\text { rejected" and "aloofness is inadmissible".44 }\end{array}$ \\
\hline "BLACK HOLE": A $\rightarrow \| \leftarrow$ B & $\begin{array}{l}\text { The black hole metaphor was probably first used for Russia } \\
\text { by Zbigniew Brzezinski (1997: 104), but it has also been } \\
\text { used by Russian authors, including nationalists. Before that, } \\
\text { the metaphor of the swamp was employed: everything that } \\
\text { ends up in it, sooner or later becomes drowned without a } \\
\text { trace. }\end{array}$ \\
\hline \multicolumn{2}{|r|}{ II. Alliance } \\
\hline ISOLATIONISM: A | X | B & $\begin{array}{l}\text { Russia has no allies, it is surrounded with enemies. The } \\
\text { following saying has been ascribed to Emperor Alexander } \\
\text { III: "Russia has only two allies - our army and navy". Such } \\
\text { understanding is quite widespread in Russia to this day. }\end{array}$ \\
\hline $\begin{array}{l}\text { ALLIANCE WITH ONE } \\
\text { AGAINST ANOTHER: } \\
\text { A X | B }\end{array}$ & $\begin{array}{l}\text { Russia has cultural and historical allies in the West, with } \\
\text { whom it has to fight against the "yellow peril". These views } \\
\text { were expressed by radical Westernizers ("zapadniki"), for } \\
\text { example, Vladimir Solov'ev. }\end{array}$ \\
\hline
\end{tabular}

5 Vladimir Putin's speech in a session of The Presidential Council for Culture and Art 24.12.2014 (https://ria.ru/culture/20141224/1039962762.html). 


\begin{tabular}{|c|c|}
\hline $\begin{array}{l}\text { ALLIANCE WITH ONE } \\
\text { AGAINST ANOTHER: } \\
\text { A | X B }\end{array}$ & $\begin{array}{l}\text { Russia has cultural and historical allies in the East, together } \\
\text { with whom it has to stand against the ruinous Western } \\
\text { civilization. This can be read in the writings of Nikolaj } \\
\text { Trubetzkoy and other Eurasians. }\end{array}$ \\
\hline \multicolumn{2}{|r|}{ III. Identity } \\
\hline $\begin{array}{l}\text { INCOMPARABILITY: } \\
\mathrm{X} \neq \mathrm{A} \neq \mathrm{B}\end{array}$ & $\begin{array}{l}\text { Russia is a completely peculiar civilization. As Fyodor } \\
\text { Tyutchev said, one cannot measure Russia, but only believe } \\
\text { in it. }\end{array}$ \\
\hline $\begin{array}{l}\text { IDENTIFYING WITH } \\
\text { ONE, OPPOSING TO } \\
\text { OTHER: } \\
\mathrm{X}=\mathrm{A} \leftrightarrow \mathrm{B}\end{array}$ & $\begin{array}{l}\text { Russia is a European country. This paradigm characterized } \\
\text { the Russian imperial power starting from Peter I, but also } \\
\text { Chaadaev and the Westernizers. }\end{array}$ \\
\hline $\begin{array}{l}\text { IDENTIFYING WITH } \\
\text { ONE, OPPOSING TO } \\
\text { OTHER: } \\
\mathrm{X}=\mathrm{B} \leftrightarrow \mathrm{A}\end{array}$ & $\begin{array}{l}\text { Russia is an Eastern country, a hidden and mysterious } \\
\text { India, which has nothing to do with the Western world. } \\
\text { These views were expressed by different mystics, as well as } \\
\text { some successors of Nicholas Roerich. }\end{array}$ \\
\hline SYNTHESIS: $\mathrm{X}=\mathrm{AB}$ & $\begin{array}{l}\text { Russia is a Eurasian country, combining the best features of } \\
\text { Europe and Asia. }{ }^{45}\end{array}$ \\
\hline
\end{tabular}

The first form of interaction is Mediator: the culture mediates the East to the West and the West to the East. The second form is Membrane, or unilateral mediation, for example, the translation of Western culture into the East. The third form could be called Isolator: the culture separates the East and the West. The final variant is the Black Hole: different influences fall into it, but nothing exits.

There are three versions of alliance. First, Russia is allied with the West and in opposition with the East. Second, vice versa, Russia is an ally of the East and opposed to the West. Third, Russia has no allies.

Identity can be divided into four different forms. First, Russia is distinctive (samobytnaya), being neither the East nor the West. Second, Russian culture is Western and in opposition to the East. Third, Russian culture is Eastern and in opposition to the West. Fourth, Russia is at the same time both the East and the West, it is a common human culture. It is remarkable that all models demonstrated above occur in the history of Russian culture.

6 "Russia is a several thousand years old synthesis of East and West. [...] Europe (West) is thesis, Asia (East) is antithesis, while Russia is a synthesis which sublates the opposites between Europe - the West and Asia - the East" (Subetto 2010: 9). 


\title{
Russian space
}

For Russian identity, the spatial dimension is of critical significance. Space is not just a place where Russia is situated, Russia itself is, first of all, a space. "Russia is a very spacious country," is the only thing that a clerk in Gogol's Dead Souls can say about Russia. And there are many other such examples. Hence, it is even more important to state that such a space has very vague limits or even no limits whatsoever. Russia is literally unlimited. On the one hand, imperialistic ambitions emanate from this Turkey, as well as the whole of Western Europe, "actually" belongs to Russia (the reason may seem curious: the geopolitical and historiosophical construction called Moscow the third Rome, while Moscow is, first of all, a tsardom, not a city; proceeding from this, the second Rome, that is, Constantinople, that is, Istanbul, but actually, Byzantium, that is, Turkey, should also be "ours", as should the first Rome and, once again, by this not the city, but the Roman Empire is meant). Figuratively, the outstanding Russian poet Tyutchev declared this in his poem "Russian geography" (1848 or 1849; it can be supposed that it was a response to the liberal criticism of Russia suffocating the fighting for freedom all across Europe).

\author{
Москва, и град Петров, и Константинов град - \\ Вот иарства русского заветные столицьы... \\ Но где предел ему? и где его границы - \\ На север, на восток, на юг и на закат? \\ $[\ldots]$ \\ Семь внутренних морей и семь великих рек... \\ От Нила до Невъь, от Эльбы до Китая, \\ От Волги по Евфрат, от Ганга до Дуная... \\ Вот царство русское... и не прейдет вовек, \\ Как то провидел Дух и Даниил предрек. ${ }^{7}$ (Tyutchev 1987: 153)
}

It is important to note that Fyodor Tyutchev was not only a poet, but also a diplomat. Nevertheless, for him, the borders of Russia are not established with international treaties but revelations, and by a very free interpretation of these: the Book of Daniel does not mention Russia at all. The spatial borders (or rather their absence) seamlessly change into temporal ones. Russian geography is a mystical historiosophy. Still, Tyutchev's text is poetry.

7 Moscow and the city of St. Peter and the city of Constantine, / these are indigenous capitals of Russia... / But where are its limits? and where is its border / towards North, East, South and the sunset? /[...] Seven inner seas and seven great rivers.../ From the Nile to the Neva, from the Elbe to China, / from the Volga to the Euphrates, from the Ganges to the Danube, / This is the Russian empire... and it never ends / like the [Holy] Spirit foresaw and [prophet] Daniel proclaimed. 
Similar constructions can be found, however, also in prose. Such ideas were so widespread that Andrey Bely starts his novel St. Petersburg with a parody of the semiofficial discourse:

\section{Your Excellences, Your Lordships, Your Honours, Citizens!}

What is our Russian Empire?

Our Russian Empire is a geographical entity, part of a well-known planet. This Russian Empire comprises in the first place Great Russia, Little Russia, White Russia, and Red Russia; in the second, the kingdoms of Georgia, Poland, Kazan, and Astrakhan; in the third place... Well, etc., etc., etc.

The metropolis is Moscow; Kiev is the mother of Russian cities. Petersburg, Saint Petersburg, or Peter (it is all one), is also part of the Russian Empire. And the Tsar-City, the City of Constantine (or, as it has been called, Constantinople) belongs to it by right of heritage. But we shall not dwell on this. (Bely 1987: $\mathrm{xxi}$ )

Compare also the Soviet joke: "On whom borders the Soviet Union?" - "It borders on whoever it wishes".

The official discourse of Russian empire evolved in the middle of the 19th century, but its more significant components had taken shape already in the 15th-16th century, partly even much earlier. Hence, in the middle of the 10th century (969 AD) a sovereign of Kiev Svyatoslav wrote this in the letter to his mother:

I do not like to sit in Kiev, I want to live in Preslav on Danube - because there is the centre of my lands, thither flow all the amenities: from the land of Greece gold, draperies, wine, different products, from Czech and Hungary silver and steeds, from Russia fur and wax, honey and slaves. (RPC, AD 969)

Despite the Slavic name, Svyatoslav was a Viking, who remembered his roots, and it happened even before his successor baptized himself, his army and, as the Russian Primary Chronicle states, the whole Russia (988). It is a typical world view of Vikings, according to which one's country is where he dwells and he can always conquer additional or even new possessions. Here it has to be emphasized that we are not just speaking about him conquering a Bulgarian town, but that of this town he intends to make a centre of his lands.

Thus, Russia is a land without fixed limits. It is, on the one hand, a ground for pride for the empire-minded people; on the other hand, it is a constant source for phobias: this land, our estate, the source and pledge of our identity may not even exist. In that case, we, Russians, do not exist either. Indeed, almost all these Russian lands which are discussed in the Russian Primary Chronicle, are now situated in Ukraine, Belarus, Lithuania. And it is not just a scholarly question, there are active battles on these 
questions on the Russian and Ukrainian websites: more aggressive nationalists of both sides are trying to prove that the other side just does not exist.

The constant proving and establishing of its existence is an inseparable part of the Russian power discourse and that at least from the 10th century onwards. Let us recall how the first text about Russian statehood, the Russian Primary Chronicle, begins: "This is the tale of bygone years ${ }^{8}$ regarding the origin of the land of Rus", the first princes of Kyiv, and from what source the land of Rus' had its beginning"10 (RPC. Laurentian Text).

The question of identity is even stronger since who is this nation Rus. The first document which is again quoted in the Primary Chronicle, but the original of which is probably a hundred years older, begins like this: "We are from Russian tribe (blood): Karl, Ingjald, Farulf, Vermund, Hrollaf, Gunnar, Harold, Kami, Frithleif, Hroarr, Angantyr, Throand, Leithulf, Fast, and Steinvith, envoys sent Oleg, the great Russian sovereign." (RPC. AD 912) There are no Slavic names in this list; also the Greek (Byzantine) sources distinguish between Slavs and Rus's in this area, the latter bear Scandinavian names and are people dominating the Slavs. And hence the question: from what source does the land of Rus' have its beginning? It is a historical trauma that constantly reminds of itself.

Hence, it is a paradoxical situation, on the one hand, we are dealing with the country with the biggest surface area in the world. The enormity of this territory is especially distinct when we look at the density of population, considering both the country as a whole and recalculating it per person. On the other hand, there is the constant motif of not having enough space, more space has to be obtained and the basis for the identity is the interspatial condition. It has to be said that such has been the dominant discourse. There have been attempts in the 20th century, first of all, by the so-called Eurasians, to transform the Russian identity to that of the Middle Kingdom: Russia is the centre of the world civilization. The same conception, however, with the significant difference of having the Soviet Union instead of Russia, was introduced by the outstanding Soviet orientalist Nikolaj Konrad (1996), according to whom the central land is what advances the civilization of the whole world. In its time, such was the Empire of Alexander the Great; after that, the Chinese civilization; and now - that is in the 1960s-1970s - the Soviet Union. Still, this is a rather marginal and purely intellectual conception which does not have any significant influence on the important constants of the Russian culture, one of the most substantial of which is

8 This is a problematic translation, 'temporary times' (time between two eternities: the bygone and the prospective) would be more precise.

9 In the original, the construction is ambivalent, it is not clear whether the land is named after the people or the people after the land.

10 From where Russia started to be. 
the interspatial condition. Here it is important between what this condition lies, how to define these forces and structures between which Russia is - and already from the early Middle Ages the opposition East vs. West has become clearly established.

Here we have to specify that we are not dealing with the geographical, but with the cultural geographical notions and these may differ a lot. For instance, Constantinople (the Second Rome) is in the South-West, Istanbul is in the East, and it is not just a question of a semantical difference or how these cities are described in texts, but also one of a practical relocation in space. When the Novgorodians went to the pilgrimage to Constantinople in the 11th century, they did not just go towards the South, but even towards the West, probably crossing the contemporary Estonian territory. But when in the 16th century the merchant Afanasij Nikitin went to Istanbul, he travelled towards the East, from the Lithuanian territory towards the Volga (of course, we have to keep in mind that his actual destination was India, but still, for him Istanbul was in the East). Even in 19th-century Russian literature, when Istanbul is discussed, it lies in the East, while when Constantinople is discussed, it is in the South or even in the West. Of course, the military-political situation must be considered, too. While in the 11th century the Novgorodians went to Constantinople through Christian lands, then for the merchants heading to Istanbul it was in every way safer to go there from the East, without crossing the Turkish and Christian front line. Nevertheless, the North-Western Constantinople and the Eastern Istanbul were fixed in the Russian geographical discourse. In it, East and West were not just directions determined from the location of the speaker, but attributes of lands and places. When Istanbul is in the East, it is in the East seen from anywhere, even if it is actually in the West in relation to the speaker.

When we speak of geography in Russian culture, we have to distinguish between the aspects which are common to all Eurasian nations, these which are common to most Indo-European nations, and then the specific Russian, or more precisely, Eastern-Slavic world view. In all Eurasian nations, as the special study showed, the opposition 'East vs. West' dominates, while the East is always the marked and positive pole (Podosinov 1999: 18-28, 455-564). The reason is obvious and not cultural, but geocosmic: the sun rises in the East and sets in the West. Hence, the East is at the same time light, warmness and often life, while the West is darkness, coldness and death. Even the explication of such an opposition shows that there is a chance - and it has been realized in all Slavish cultures - that the cultural East merges with the South, while the West merges with the North. Geographically it could mean that the real direction to the "East" is to the South-East, while that to the "West" is the North-West. Such a world view is characteristic already of the Pre-Christian, the so-called pagan, conception of the world. The Christian world view was synthesized with that, adding some important nuances. 
Archbishop Vasilij of Novgorod noted in his letter to Bishop Feodor of Tver' (14th century) that Paradise is situated in the East:

...We all know from the Holy Scripture that God planted paradise in the East, in Eden [...] And in the "Paremii" four rivers are mentioned that flow from paradise: the Tigris, the Nile, the Phison and the Euphrates; the Nile is located in the region of Egypt, [...] and it springs from high mountains that reach from the earth into the sky, ant that place is inaccessible to men, and on its top live the rakhmans.

Hell, on the other hand, is situated in the West:

John Chrysostom wrote: "God has planted paradise in the East, but in the West." He has prepared the torments... [...] Furthermore, Brother, God has not given to men to behold holy paradise, but the place of torments is to this day located in the West. Many of my spiritual children from Novgorod have seen it on the Blowing Sea: an ever-watchful serpent, and gnashing of teeth, and a seething river called Morg and the waters enter the underworld there and return from it three times a day. (Luttikhuizen 1999: 191-192)

Hence, it is revealed that the West is situated in the North, on the Blowing Sea (that is, the Arctic Ocean), while the East is in the South. ${ }^{11}$ The West-East opposition is multidimensional and asymmetrical: the East is high and located in the South, the West is low and located in the North; one has to strive to the East, but it is invisible and unreachable during one's lifetime, while the West means a constantly threatening actual danger - one has to be cautious so as not to get there. What is especially interesting in the context is the mention of 'rakhmans', since it is the first mention of brakhmans in Russian texts: it is remarkable in every way that according to the bishop, the rakhmans are residents of the (Christian) paradise.

11 Here, biblical text is probably interpreted through the prism of the Slavish model of space. The biblical Eden from where the river flows, breaking up to the Phison, the Gehon (not the Nile!), the Tigris and the Euphrates, is situated "on the side of the sunrise", so it is natural to assume that hell must be located in the opposite direction. As for Paradise, the biblical text does not present any geographical difficulties: Eden is situated East of Palestine, with some concessions it applies also to Antiochia and even to Constantinople (John Chrysostom is, first of all, connected with these places), yet in no way does it apply to Novgorod. In these, at the first sight, curious deliberations by Bishop Vasilij a reflection of the common Slavish system of space can be noticed.

"The opposition south-north is as well as isomorphous with the opposition east-west, while the first (positive) part of the opposition is associated with sun, day, summer, warmness, but the second one with moon, night, winter, coldness" (Ivanov, Toporov 1965: 112; see also Podosinov 1999: 371-373). 
This model of space can be considered universal or, at any rate, it appears to be remarkably persistent; we could say that it reflects no less than the common Slavish vision. So, in the opposition of the East and the West it is the East that appears to be the marked member of opposition.

The space of Russia is heterogeneous, some parameters appear to be substantial, while others seem not to exist at all. The determinate circumstance is the direction from the East to the West, there is no South at all: Russia is a Northern country. The same is the matter with the vertical dimension: there are no mountains, but there are abysses, or to be more correct, this whole endless plain desert, wasteland - is an abyss or at least a hollow, a hole (cf. Andrej Platonov's novel The Foundation Pit from 1930).

The East and the West are not just about different parts of the world, but also concern the principles of world order. Pyotr Chaadaev had a key role in establishing the Russian political discourse. His pupils were of different ideological trends, both Westernizers and Slavophiles, and it is not so much Chaadaev's ideas as the discourse he created that is important. In his Apologia of a Madman he wrote:

The world has from all time been divided into two spheres, the East and the West. This is not a geographical division, it is an order of things which develops from the very nature of intelligent being. East and West are two principles which correspond to two dynamic natural forces, two ideas which encompass the whole economy of mankind. In the East the spirit of man found its power in self-concentration, in meditation, in shutting itself up within the sphere of its own activity; in the West it developed by spreading outward, by radiating in all directions, by struggling with all obstacles. Society was naturally set up on the basis of this primitive data. In the East the intellect retired within itself, took refuge in repose, hid in the desert, and allowed the power of social position to become master of all goods of the earth; in the West the intellect spread out in all directions, embraced all the needs of men, aspired to all goods, based power on the principle of law. (Chaadaev 1991: 106)

Let us note first that according to Chaadaev, the huge scope of the East is oppressing to man in every way, while in the restrained Western space one feels oneself liberated - in every sense of this word. Now to the main point: it seems that this fragment is another variation on the theme: „Oh, East is East, and West is West, and never the twain shall meet...", but in a way, Chaadaev's standpoint is quite contrary to that of Kipling's. First, according to Kipling, the belonging of Britan to the West is an axiom, colonization means the expansion of the Western sphere: second, an Englishman always carries his West along with him. But for Chaadaev, the belonging of Russia to the West is rather a theorem which he is passionately trying to prove, at the same time polemizing with the "new direction" (that is, the Slavophiles), which is claiming the opposite: "With the flow of passion this newborn patriotism rushes to declare us the favourites of the East". 
Thus, for Chaadaev the question of the Russian territorial belonging to the East or to the West had not found the final solution. The same has to be said about the people inhabiting this territory: they do not subject the space to themselves; on the contrary, they appear to be completely dependent on the qualities of the surrounding space. By the way, there is one more surprise: it appears that Russians belong to the West, because they are... Northern people: "We live in the European East - that is true, and nevertheless, we have never belonged to the East. We simply are a Northern people by virtue of our ideas as well as our climate, far removed from the fragrant valleys of Kashmir and the sacred banks of the Ganges." 12

Consequently, Chaadaev's geography reveals traces of the common Slavish model of space, which equates the West to the North and the East to the South. It has to be said, though, that in Chaadaev, this model is reverse: the West is the positive member of opposition. In this context, special meaning is given to several forms of relocation in space; very often a relocation in the geographical space is related to a simultaneous movement in the ideological space (the coordinates of space can be signified by different, although mutually connected categories: 'East/West,' 'sacral/profane, "'own”/ strange' etc, an invariant is the opposition of the "right" and the "wrong" space. But Chaadaev's logic is even more complicated: he replaces the privative opposition with the ambivalent one, introducing the South-North dimension to the opposition EastWest - Russia is West, because it is North.

The opposition 'Christian/pagan' was connected with the opposition 'Slavonic/ Nemets', later 'Russian/Nemets (German)'. As it is known, 'Nemets' (German) is not as much the name of a representative of a concrete nation, but rather a reference to his foreignness (if necessary, the nationality of a "German" could have been specified, e.g., English German [anglijskij nemets], etc). Etymologically, the word 'Nemets' is not completely transparent, the most probable is its derivation from 'dumbness'. The latter was interpreted in a wide sense as tongue-tie and stuttering. This interpretation is supported by folk etymology which opposes Germans as dumb to Slavonians, the latter term being clearly related to 'word' (slovo). Yet 'a German' is not just any foreigner, but a foreigner of Western origin. Initially, there was no analogical general name for Eastern foreigners; after contacts with the Islamic world emerged, the word 'busurman' was used in this function. Still, it has to be noted that the marked member in this privative opposition is the Oriental direction: a German, French or Catholic could have been called a busurman, but an Easterner could not be called German.

12 In claiming that "East - it is South", Chaadaev follows the archaic model and he is by far not the only one to do so; let us see a present-day variation on this theme: "Russia cannot be on the side of the East in any way - for the last two centuries it has meant the aggressive South for it" (Kol'ev 1998: 314). 
The study of glossophobia in Russian culture (Lotman, M. 2004) ${ }^{13}$ allows us to make some specifications in the sphere of the semiotics of fear in Russian culture. Fears in Russian culture are connected with the geographical position on the East-West axis (culturally, East and West do not necessarily coincide geographically: often South is called East and North is called West). Dangers related to the West are principally different from those of the East. The West is dangerous because of its rationality which destroys individuality (Western authors often contrast Russian collectivism with Western individualism, while from the perspective of Russian culture this contrast is not correct). The West is logical, blabbering and deceitful; Eastern dangers, on the other hand, are speechless. On the one hand, the "yellow danger" is beyond reason and word; on the other hand, its nature is like that of a nightmare: it is so horrible that one becomes speechless.

\section{Conclusion}

Russian space is structured with the East-West axis. The position of Russia itself on this axis is determined by ideological factors. The main models which are observed are the following:

(1) Russia is an Eastern country;

(2) Russia is a Western country;

(3) Russia is neither an Eastern nor a Western country, but something peculiar;

(4) Russia is neither an Eastern nor a Western country, but a shield between the East and the West;

(5) Russia is both an Eastern and a Western country, Eurasia.

In mid-1990s a sociological poll was conducted to find out which country constitutes the biggest threat to their country according to Russians. It appeared to be Latvia (Estonia was in the third or the fourth place). ${ }^{14}$ A liberal Moscow newspaper concluded that Russians were stupid, as not only did they see a non-existing threat, they also had closed their eyes to the real threat, China, as Chinese nationals were secretly inhabiting vast areas in Far-East and North Siberia and would constitute the majority of the population there in the near future.

13 Differently from psychology, where the term 'glossophobia' is used for the fear of performance, in the semiotics of culture it means the complex of ideas and mentalities, according to which foreign languages are harmful and dangerous - cf. the idea that foreign language can cause drought (Uspenskij 1996b: 486-493). It has to be kept in mind that in the medieval Russian culture the word 'language' (yazyk) did not signify Slavic, but only foreign languages (Lotman 2004).

14 I was not able to recover either the results of this poll or the discussions of it any more, but a recent poll (May 2017) again places Latvia and Lithuania at the top of the list of countries most hostile to Russia (http://www.levada.ru/2017/06/05/druzya-i-vragi-rossii-2/). 
This is typical: the threat emanates either from the West or from the East and its nature is different in principle - just like it scares people who are different in principle: fears evoke a particular text, which, in turn, chooses its audience.

The danger emanating from the West is the danger of anonymizing and soulless structure, a danger to be measured with the "common yardstick" (Tyutchev). The threat coming from the East, however, is vast, impersonal and silent: on the one hand, Asians are quietly attacking, on the other hand, the weak-willed Russians who are paralyzed with (false) fears are silent about this as well.

\section{References}

Bely, Andrey 1987. St. Petersburg. (Cournos, John, trans.) New York: Grove Press.

Berdyaev, Nikolaj 1910. Rossiya i zapad. In: Duhovnyj krizis intelligentsii. Stat'i po obshchej i religioznoj psihologii (1907-9 g.). St. Petersburg. Obshchestvennaya pol'za, 120-128. [Бердяев, Николай 1910. Россия и Запад. In: Духовный кризис интеллигенции. Статьи по общей и религиозной психологии (1907-9 г.) Санкт-Петербург: Общественная польза, 120-128.]

- 1918. Sud'ba Rossii (Opyty po psihologii vojny i natsional'nosti). Sbornik statej 1914-1917. Moscow: Izdatel'stvo G. A. Lemana i S. I. Saharova. [Бердяев, Николай 1918. Судьба России (Опыты по психологии войны и национальности). Сборник статей 1914-1917. Москва: Издательство Г. А. Лемана и С. И. Сахарова.]

Brzezinski, Zbigniew 1997. The Grand Chessboard: American Primacy and Its Geostrategic Imperatives. Philadelphia: Perseus Books.

Chaadaev, Peter 1991. Apologia of a Madman. (Zeldin, Mary-Barbara, trans.) In: Philosophical Works of Peter Chaadaev. Berlin: Springer.

Chkhartishvili, Aleksandr (ed.) 2000. Kalendarnyj vopros: Sbornik statej. Moscow: Izdatel'stvo Sretenskogo monastyrya. [Чхартишвили, Александр (Ред.) 2000. Календарный вопрос: Сборник статей. Москва: Издательство Сретенского монастыря.]

Gulyga, Arsenij 1995. Russkaya ideya i ee tvortsy. Moscow: Soratnik. [Гулыга, А. В. 1995. Русская идея и её твориьь. Москва: Соратник.]

Ivanov, Vyacheslav; Toporov, Vladimir 1965. Slavyanskie yazykovye modeliruyushchie semioticheskie sistemy. Moscow: Nauka. [Иванов Вяч. Вс.; Топоров, В. Н. Славянские языковые моделирующие семиотические системы. Москва: Наука.]

Javornik, Miha 1994. Evangelij Bulgakova: o ustvarjalnosti Mihaila Afanasjeviča Bulgakova. Ljubljana: Znanstveni inštitut Filozofske fakultete.

Kalokh-Vid, Natal'ya 2014. Apokalipticheskie motivy v povesti M. A. Bulgakova Rokovye yajtsa. Izvestiya Yuzhnogo federal'nogo universiteta. Filologicheskie nauki 2: 45-53. Калох Вид, Наталья 2014. Апокалиптические мотивы в повести М.А. Булгакова «Роковые яйца». Известия Южного федерального университета. Филологические науки 2: 45-53.

Kol'ev, Andrej 1998. Mif mass i magiya vozhdej. Moscow: Natsional'nyj institut razvitiya. [Кольев, А. (А. Н. Савельев) 1998. Миф масс и магия вождей. Москва: Национальный институт развития.] 
Konrad, Nikolaj 1996. Perepiska N. I. Konrada i A. Dzh. Toinbi. In: Neopublikovannye raboty. Pis'ma. Moscow: Rosspen, 397-432. [Конрад, Н. И. 1996. Переписка Н. И. Конрада и А. Дж. Тойнби. In: Н. И. Конрад, Неопубликованные работы. Письма. Москва: Росспен, 397-432.]

Lebedev, Gleb 1995. Epoha vikingov v Severnoj Evrope. Leningrad: Izdatel'stvo LGU. [Лебедев, Г. С. 1995. Эпоха викингов в Северной Европе. Ленинград: Издательство ЛГУ.]

Lomonosov, Mikhail 1952. Predislovie o pol'ze knig tserkovnyh v rossijskom yazyke. In: Polnoe sobranie sochinenii. Vol. 7: Trudy po filologii 1739-1758 gg. Moscow-Leningrad: Izdatel'stvo AN SSSR, 585-592. [Ломоносов, М. В. 1952. Предисловие о пользе книг церковных в российском языке. In: Ломоносов М. В. Полное собрание сочинений. Т. 7: Труды по билологии 1739-1758 г2. Москва-Ленинград: Издательство АН СССР, 585-592.]

Lotman, Juri 1984. Simvolika Peterburga i problemy semiotiki goroda. Trudy po znakovym sistemam [Sign Systems Studies] 18: 30-43 (Special issue Semiotika goroda i gorodskoj kul'tury). [Лотман, Ю. М. 1984. Символика Петербурга и проблемы семиотики города. Труды по знаковым системам. Семиотика города и городской культуры. 18: 30-43.]

- 1992. Mehanizm smuty: (K tipologii russkoj istorii kul'tury). Studia Russica Helsingiensia et Tartuensia 3: Problemy russkoj literatury i kultury / Slavica Helsingiensia 11: 7-23. [Лотман, Ю. М 1992. Механизм Смуты: (К типологии русской истории культуры). Studia Russica Helsingiensia et Tartuensia 3: Проблемь русской литературы и культурь / Slavica Helsingiensia 11: 7-23.]

- 2009. Culture and Explosion. (Clark, Wilma, trans.) Berlin: Mouton de Gruyter.

Lotman, Juri; Uspenskij, Boris 1977 Rol' dual'nyh modelej v dinamike russkoj kul'tury (do kontsa XVIII veka). Trudy po russkoj i slavyanskoj filologii XXVIII: Literaturovedenie. K 50-letiyu professor Borisa Fedorovicha Egorova. Tartu: TGU, 3-36. [Лотман, Ю. М.; Успенский, Б. А. 1977. Роль дуальных моделей в динамике русской культуры (до конца XVIII века). Труды по русской и славянской филологии. ХХVIII: Литературоведение. К 50-летию профессора Бориса Федоровича Егорова. Тарту: ТГУ, 3-36.]

- 1982 Otzvuki kontseptsii “Moskva - tretij Rim" v ideologii Petra Pervogo (K probleme srednevekovoj traditsii v kul'ture barokko). In: Karpushin, V. A. (ed.), Hudozhestvennyj yazyk srednevekov'ya. Moscow: Nauka, 236-249. [Лотман, Ю. М., Успенский, Б. А. 1982. Отзвуки концепции «Москва - третий Рим» в идеологии Петра Первого (К проблеме средневековой традиции в культуре барокко). In: Карпушин, В. А. (ред.), Художественный язык средневековья. Москва: Наука, 236-249.]

Lotman, Mihhail 2004. Glossophobia in Russian culture. In: Lotman, Mihhail (ed.), Kultuuri maailmad. Cultural Worlds. (Acta collegii humaniorum estoniensis 4.) Tallinn, 104-117.

- 2005. O semiotike straha v russkoj kul'ture. In: Buks, Nora; Kont, Fransis (eds.), Semiotika straha. Paris, Moscow: Evropa. 13-35. [Лотман, Михаил 2005. О семиотике страха в русской культуре. (Букс, Нора; Конт, Франсис, ред.) Семиотика страха. Сорбонна, Русский институт. Париж-Москва: Европа, 13-35.]

- (in press). Towards the semiotics of (in)sincerity.

Luttikhuizen, Gerard P. (ed.) 1999. Archbishop Vasili of Novgorod's epistle to bishop Fyodor of Tver. (Brouwer, Sander, trans.). In: Luttikhuizen, Gerard P. (ed.), Paradise Interpreted. Representations of Biblical Paradise in Judaism and Christianity. Leiden: Brill, 190-196.

Orwell, George 1950. Nineteen Eighty-Four. London: Signet Classics. 
Podosinov, Aleksandr 1999. Ex oriente lux! Orientatsiya po stranam sveta $v$ arhaicheskih kul'turah Evrazii. Moscow : Yazyki russkoj kul'tury. [Подосинов, А. В. 1999. Ex oriente lux! Ориентация по странам света в архаччески культурах Евразии. Москва: Языки русской культуры.]

RPC 1953 = The Russian Primary Chronicle. Laurentian Text. (Cross, Samuel; SherbowitzWetzor, Olgred P., trans., eds.) Cambridge: Medieval Academy of America.

Segal, Dimitri 1992. Istoriya I poetika u Mandel'shtama: Stanovlenie poeticheskogo mira. [История и поэтика у Мандельштама: Становление поэтического мира.] Cahiers $d u$ monde russe et soviétique 33(4): 447-495.

Subetto, Aleksandr 2010. Noosfernyj proryv v budushchee Rossii v XXI veke. St. Petersburg: Asterion. [Субетто, А. И. 2010. Ноосферный прорыв в будущее России в ХХІ веке. Санкт-Петербург: Астерион.]

Toporov, Vladimir 1984. Peterburg i peterburgskij tekst russkoj literatury. Trudy po znakovym sistemam [Sign Systems Studies] 18: 4-29 (Special issue Semiotika goroda i gorodskoj kul'tury). [Топоров, В. Н. 1984. Петербург и петербургский текст русской литературы. Труды по знаковым системам 18: 4-29. (Семиотика города и городской культуры)]

- 2009. Peterburgskij tekst. Moscow: Nauka. [Топоров, В. Н. 2009. Петербургский текст. Москва: Наука.]

Tyutchev, Fyodor 1987. Polnoe sobranie stihotvorenij. Leningrad: Sovetskij pisatel'. [Тютчев Ф. И. 1987. Полное собрание стихотворений. Ленинград: Советский писатель.]

Unbegaun, Boris 1971. Russkij literaturnyj yazyk: problemy i zadachi ego izucheniya. In: Alekseev, M. P. (ed.), Poetika i stilistika russkoj literatury. Pamyati akademika Viktora Vladimirovicha Vinogradova. Leningrad: Nauka, 329-333. [Унбегаун, Б. 1971. Русский литературный язык: проблемы и задачи его изучения. In: Алексеев, М. П (отв. ред.), Поэтика и стилистика русской литературы. Памяти академика Виктора Владимировича Виноградова. Ленинград: Наука, 329-333.

Uspenskij, Boris 1994. Dualisticheskij harakter russkoj srednevekovoj kul'tury (na materiale "Hozheniya za tri morya" Afanasiya Nikitina). In: Izbrannye trudy. Vol. 1. Semiotika istorii. Semiotika kul'tury. Moscow: Gnoziz, 254-297. [Успенский, Б. А. 1994. Дуалистический характер русской средневековой культуры (на материале «Хожения за три моря» Афанасия Никитина). In: Избранные трудь. T. 1. Семиотика истории. Семиотика культуры. Москва: Гнозис, 254-297.

- 1996a. Anti-povedenie v kul'ture drevnej Rusi. In: Izbrannye trudy. Vol. 1. Semiotika istorii. Semiotika kul'tury. Moscow: Yazyki russkoj kul'tury, 460-476. [Успенский, Б. А. 1996а. Анти-поведение в культуре древней Руси. In: Избранные труды. T. 1. Семиотика истории. Семиотика культуры. Москва: Языки русской культуры, 460-476.]

- 1996b. Raskol i kul'turnyj konflikt XVII veka. In: Izbrannye trudy. Vol. 1. Semiotika istorii. Semiotika kul'tury. Moscow: Yazyki russkoj kul'tury, 477-519. [Успенский, Б. А. 1996а. Раскол и культурный конфликт XVII века. In: Избранные труды. T. 1. Семиотика истории. Семиотика культуры. Москва: Языки русской культуры, 477-519.]

- 1998. Tsar' i Patriarh: harizma vlasti v Rossii (Vizantijskaya model' i ee russkoe pereosmyslenie). Moscow: Yazyki russkoj kul'tury. [Успенский Б. А. 1998. Царь и Патриарх: харизма власти в России (Византийская модель и ее русское переосмысление). Москва: Языки русской культуры.] 
- 2002. Istoriya russkogo literaturnogo yazyka (XI-XVII vv.). (3rd, revised ed.) Moscow: Aspekt Press. [Успенский, Б. А. 2002. История русского литературного языка (XI-XVII вв). (3-е издание, исправленное и дополненное.) Москва: Аспект Пресс.]

Uspenskij, Fyodor 2002. Skandinavy. Varyagi. Rus': Istoriko-filologicheskie ocherki. Moscow: Yazyki slavyanskoj kul'tury. [Успенский, Ф. Б. 2002. Скандинавы. Варяги. Русь: Историко-филологчческие очерки. Москва: Языки славянской культуры.]

\section{История как география: в поисках русской самости}

В статье рассматриваются те аспекты русского хронотопа, в которых пространственные параметры конституируют наиболее существенные константы российской истории. Культурная константа не зависит от господствующей идеологии, она в равной мере характеризует и оппозиционные взгляды и движения. Варьируются оценочные, т.е. наиболее поверхностные семантические компоненты: то что составляет предмет гордости для одних является позором для других, однако само наличие соответствующих констант даже не обсуждается. В статье предлагается типология промежуточности. Примечательно, что в идеологическом пространстве русской культуры реализуются все теоретически возможные конструкции.

\section{Ajalugu kui geograafia: vene identiteedi otsinguil}

Artiklis käsitletakse neid vene kronotoobi aspekte, milles ruumilised parameetrid konstitueerivad tähtsaimaid Venemaa ajaloolisi konstante. Kultuuriline konstant ei sõltu valitsevast ideoloogiast, see iseloomustab võrdselt ka opositsioonilisi vaateid ja liikumisi. Varieeruvad aga hinnangulised, st kõige pealispindsemad semantilised komponendid: see, mis on ühtedele uhkuseasi, on häbiks teistele, kuid vastavate konstantide olemasolu ei kuulu isegi arutlusele. Artiklis pakutakse välja vahepealsuse tüpoloogia. On märkimisväärne, et vene kultuuri ideoloogilises ruumis realiseeruvad kõik teoreetiliselt võimalikud konstruktsioonid. 